\title{
Neoliberalism, Polanyi's Protective Response, and Veblenian Waste
}

\author{
Mary V. Wrenn \\ Joan Robinson Research Fellow in Heterodox Economics \\ Girton College \\ University of Cambridge \\ mw561@cam.ac.uk
}

Key words: Veblen, Polanyi, economic surplus, neoliberalism

JEL: B52, N32, P10, Z10

\begin{abstract}
:
As capitalism unfolds, continual technological advance in combination with the relentless accumulation imperative serves to amplify material progress. The expanding economic sphere begins to pervade the everyday lives and thinking of the individual. The institutionalization of the market fundamentally changes the structure of society and in so doing, fundamentally changes the institutional structure through which individuals are socialized. The social dislocation generated therein, prompts Polanyi's protective response.

Despite this market intensification, the existence of the economic surplus undermines the syllogistics of market determined pricing. Evidence of the economic surplus and Veblenian waste and furthermore, that the competitive law of value is not operable under neoliberalism is found in the lobby industry and campaign contributions. This research seeks to connect explicitly the concepts of Polanyi's protective response with Veblenian waste and the economic surplus in order to better understand how the irrational system of neoliberalism continues to evolve.

Biographical note:

Mary V. Wrenn is the Joan Robinson Research Fellow in Heterodox Economics at Girton College, University of Cambridge. Mary's other research interests include locating ontological concepts such as agency, identity, and emotions within the historical framework of neoliberalism. This paper was presented at the annual meeting of the Association of Evolutionary Economics, January 2016 in San Francisco.
\end{abstract}




\section{The Economic Surplus Fund and Veblenian Waste}

The concept of the economic surplus in its most basic form consists of the difference between what is produced and that production which is needed to reproduce society in the next period. The economic surplus so defined is not contextually specific and therefore is applicable to all societies and production forms (Heilbroner 1985). The production of an economic surplus hence requires production beyond the subsistence level of output for a society (Lichtenstein 1983). Within the context of the latest stage in the evolution of capitalism - that of monopoly capitalism - the economic surplus is more specifically defined as what is left from potential output once essential consumption - that is, the consumption necessary for social and material reproduction has been met. Potential output is not the amount of output produced in a period, but rather consists of the total productive capacity, whether utilized or not, for the given level of capital stock and workforce talent in a society. In other words, potential output is the output that is attainable if all the available factors of production in a society are employed (Stanfield 1984). That actual output often falls short of potential is a tendency of monopoly capitalism; i.e., a tendency towards excess capacity.

Any expenditure that contributes to the social and material reproduction of society, including maintenance of an individual's previous standard of living as well as maintenance of the previous period's productive capacity constitutes essential consumption. Consumption that increases capacity or more than reproduces society should be considered investment rather than consumption per se and as such, a potential catalyst to economic growth and development. Since it is through the economic surplus that this investment is funded, it is clear that the potential for the direction and content of growth resides in the deployment of the economic surplus fund 
(Stanfield 1992, 1984). The economic surplus should therefore be considered a fund, regardless of what the fund might finance.

Because of the insatiability of the accumulation cycle which drives all capitalist systems, business interests must constantly and consistently expand production. Given the similar drive to contain costs, specifically labor costs, structural imbalance is created by the gap between productive capacity and consumption limits; the former defined by the state of technology, the latter by the prevailing social and political institutions and the distribution of income (Stanfield 1977). The structural inequality of the distribution of income endemic to all varieties of capitalism constrains the amount of production that can be consumed within a given society. The problem of ineffective demand or underconsumption plagues modern business.

Modern day crisis under the monopoly capital system is thus the crisis of chronic excess capacity, which cannot be used to produce more consumer goods, given the inequality of the distribution of income, and cannot be used for investment, i.e., to produce productivity enhancing capital, as this compounds the problem of excess capacity (Foster 2000). While the economic surplus consists of the gap between potential output and essential consumption, the gap between productive capacity and the limits to consumption might be conceptualized as the structurally determined portion of the economic surplus fund and thus directly reflects the degree of excess capacity within a given time period. Chronic excess capacity and idle capital stock brought about by the accumulation of surplus funds and underconsumption creates a systemic tendency towards stagnation under monopoly capitalism (Foster 1984; Wrenn 2010).

Government spending, especially within the growing movement to privatization, exhausts the economic surplus fund by closing the gap between productive capacity and now increasing 
public sector consumption (Wrenn 2014). As early as 1957, Baran pointed out that such stimulation within the monopoly capitalist system encourages business overestimation of demand elasticity which in turn encourages production beyond the limits of consumption, thereby amplifying the economy's tendency toward stagnation and consequently cycles back the need for further government stimulus of the economy. Moreover, financing unstructured investment through government deficits especially in non-capital stock increasing investment, such as military armaments and technological research would result in precarious inflationary overhang (Baran 1957; Foster 1984).

The key consequents of a monopoly capitalist system therefore are structural maladjustment and stagnation (Mott 1992). The systemic tendency towards stagflation emerges from the underlying tendencies of modern monopoly capitalism toward chronic excess capacity, idle capital stock, and surplus funds in frozen suspension awaiting government assistance, correlated with the tendency to inflationary overhang, worsened by unstructured government deficit financing in order to commission output to forestall the threat of the former (Foster 1984). Given these tendential laws, it would seem as though the modern monopoly capitalist system would eventually be swallowed by its own stagnationist crises. The modern social structure of accumulation, however, has proven quite adept at forestalling such crises through the creation of non-productive venues of expending economic surplus funds.

Given the limits on consumption imposed by the inequality of the distribution of income and the consequent need to expand productive capacity while avoiding the creation of idle capital, the modern capital system of monopoly capitalism creates a means of producing what Veblen referred to as 'waste.' 
Veblen used the term 'waste' frequently throughout his works; his definition of waste changing slightly to fit the respective context. This is not to suggest that Veblen used the term with any inconsistency; indeed, despite shades of differences in the application of the term, a coherent and consistent concept of the term 'waste' emerges from a holistic view of Veblen's work: Veblenian waste is the deployment of resources in ways that do not contribute to overall social welfare or to the welfare of the generic individual. This is clear in the two different, yet consistent ways in which Veblen describes waste in two of his most popular works. Waste as Veblen describes in the Theory of the Leisure Class (TLC) (2007) includes conspicuous and ceremonial expenditure and resources put toward the maintenance of invidious distinctions, whether at the state or individual level. Waste as described in the Theory of Business Enterprise (TBE) (2005) captures non-productive use of resources and capital, whether that non-productive use means preventing idleness of capital or the use of capital and resources into production of goods and services that do not contribute to the overall welfare of society:

That is to say in other words, the absorption of goods and services by extra-industrial expenditures, expenditures which as seen from the standpoint of industry are pure waste, would have to go on in an increasing volume. If the wasteful expenditure slackens, the logical outcome should be a considerable perturbation of business and industry, followed by depression; if the waste on war, colonization, provincial investment, and the like, comes to an abrupt stop, the logical consequence, in the absence of other counteracting factors, should be a crisis of some severity (120).

Both definitions of waste in TLC and TBE align with discussion of how the economic surplus might be used; for present purposes, the emphasis will fall on Veblenian waste as described in the 
TBE. Of particular concern here is the government expenditure which is tethered through lobbying efforts to the monopoly capital system.

\section{The Polanyian Protective Response and Neoliberalism}

As capitalism evolves, continual technological advance in combination with capital's relentless accumulation imperative serves to amplify material progress. The expanding economic sphere begins to pervade the everyday lives and thinking of the individual. The institutionalization of the market fundamentally changes the structure of society and in so doing, fundamentally changes the institutional structures through which individuals are socialized. As such, the socialization process becomes increasingly accommodating to the intensifying market place and the transference of knowledge, tradition, and culture via the social structure all become increasingly tinged by the values of the market.

As well, the increasing momentum of market intensification in monopoly capitalism encourages the extraction of the market from the other spheres of social life, in other words, the disembedding of the economic sphere. In following the logic of its own momentum, the economic sphere enlarges eventually encompassing the entirety of social life, subordinating the other spheres of livelihood to support its purpose and further intensification (Polanyi 1944). The concurrent intensification of the market mentality and the continued disembedding of the economy drives a deeper wedge into the development of personal relationships as anonymity of the market, pecuniary values, and the competition of emulation serve to distance individuals from one another by eroding, preventing, or calling into question social bonds and collective goals (Stanfield 1996). Although Polanyi wrote about monopoly capitalism prior to the emergence of neoliberalism, his work, particularly his description and elucidation of the disembedded economy nevertheless 
describes quite clearly how neoliberalism emerged and continues to evolve (Dale 2010): the superiority of the individual over the collective is the guiding principle and rallying cry of neoliberalism.

Neoliberalism is the prevailing ideological operant of the most recent stage in the evolution of monopoly capitalism over the last nearly five decades. Neoliberalism embodies the ideological shift in the purpose of the state from one that has a responsibility to insure full employment and protect its citizens against the exigencies of the market to one that has a responsibility to insure protection of the market itself (Harvey 2005). The neoliberal narrative consists of three welldefined tropes: privatization of currently state provided goods and services, de-regulation of industry, and retrenchment of the welfare state (Dumenil 2011). All three reinforce a central premise: the locus of control is the individual exercising agency through (free) market operations. Furthermore, neoliberalism teaches through the socialization process that each individual should be accountable to herself and in so doing, each individual's responsibility to others and to the collective is eroded. Society is then comprised entirely and solely of self-interested, atomistic individuals seeking to forward their own agendas. The emphasis on individual accountability and responsibility naturally segues into the power of the individual acting alone.

The intensification of the marketplace and market mentality creates a vacuum in the lives of individuals left by the social dislocation created by the disembedded economy and the subordination of social life to the dictates of the market. The social dislocation generated by the market mentality and the intensification of the market, prompts Polanyi's protective response. Individuals seek meaning, order, and the means for social continuity in daily living and look to the 
major social institutions to serve that function as an integrating mechanism and provide opportunities for citizens to address social concerns and seek amelioration (McClintock 1998).

The social protective response which rises against the dehumanization of market intensification and increasing social dislocation prompts the construction of provisions and programs of the welfare state, but in an unorganized, ad hoc fashion primarily as a result of its spontaneity and pragmatic immediacy. The welfare state is thus not a systematic creation of social protection measures, but rather a product of the uncoordinated efforts to ameliorate immediate concerns.

This is not to say that all protective responses are uncoordinated, indeed business interests forge alliances with competitors, as evidenced by trade associations, as well as across industries in collective efforts to maintain positions of power over government and labor. Business interests as well, seeks protection from the intensified market setting. Indeed, despite the free market rhetoric, neoliberalism does not advocate complete abstention of government intervention in the market; business interests still rely upon the state to provide refuge from the exigencies of the market. To stem stagnation, business interests depend on the state to help exhaust excess capacity and to ameliorate underconsumption through government commanded production; preferably production that is contracted out to the private sector. Likewise, business interests pursue regulatory restructuring in order to pare away specific regulations that diminish profitability or impede the movement of capital while maintaining interventions that support or create markets. The state is also relied upon as a resource in cost containment with respect to labor; the depressed wages and rising inequality which are products of the neoliberal project work to the advantage of business interests by acting as a disciplinary device for labor to insure loyalty and productivity and 
a means for keeping inflation down. Moreover, the retrenchment of the welfare state is an important disciplinary device for business interests to insure a compliant labor force; by removing social programs, workers are forced to work without a safety net and become willing to take almost any job under almost any conditions (Piven 2004; Wrenn 2014).

It is the conflicting interests of these collective groups and the continued lack of collective action from the citizenry writ large however that fuels the ad hoc creation and contradictory character of the welfare state. The estrangement of the state from the general public has placed the welfare state in great peril. The divide has been both deliberate and an unintended consequence; deliberate in the harnessing of state discretion to business interests and unintendedly as the result of institutional drift. What stymies the coordination of the social protective response and perpetuates the institutional drift in the creation of the welfare state is the pervasiveness of the market, especially within political institutions, which requires that all protective responses be framed in the rhetoric of and in support of the market. As a result, the focus of reform has been on ameliorating specific symptoms of crises as opposed to addressing the structural problems of the system of monopoly capitalism or the fundamental flaws in the guiding principles of neoliberal ideology.

\section{Polanyian Protection and Veblenian Waste: Evidence from the US}

The complexity and volume of legislation that passes over a Congressperson's desk- as well as all the iterations of any given piece of legislation - necessitates her/his reliance on other individuals both inside and outside of Congressional offices for information and insight on the various and wide-range of issues that might be encapsulated in even a single legislative bill. With an eye toward allowing industry expertise to help guide the Congressperson in making informed 
decisions, representative advocates - lobbyists - are sent to policy makers to educate Congress members and to assist in crafting, tweaking, or blockading that legislation which will impact their clientele. And lobbying is big business.

Over the seventeen year period of study from 1998 to 2014 (inclusive), organizations both business interests and labor/general special interests more than doubled the amount of money spent each year on lobbying: from $\$ 1.45$ billion spent in 1998 to $\$ 3.2$ billion spent in 2014. The most alarming revelation, however, comes from the comparison between the total amounts business interests spent on lobby efforts versus that which labor and general special interests spent over that seventeen year timeframe (see Table 1 and Chart 1).

\author{
Place marker: Table 1 here \\ Place marker: Chart 1 here
}

In the case of lobbyists, the protective response from business interests overshadows and overwhelms the protective response from workers and special interests. It is clear that business interests find lobbying to be a direct means by which to craft and shape business-friendly legislation, and that any efforts on the part of workers or the general public are swallowed by the sheer volume of dollars business interests not only have at their disposal through the economic surplus fund, but are willing to put toward lobbying efforts.

\title{
$\underline{\text { Concluding Remarks }}$
}

The tendential logic of monopoly capitalism toward excess capacity and idle capital stock makes the creation of wasteful output a necessary but still ultimately profitable endeavor. Lobby efforts are made all the more attractive by virtue of their inability to expand productive capacity and compound the excess capacity problem. As the above evidence clearly demonstrates, the 
economic surplus is a fund for Veblenian waste, and one of the most efficient means of nonproductivity expanding investment is investing in Polanyi's protective response: the education of state officials in how to structure a welfare state amenable to the goals of business interests and which will sustain a favorable distribution of income.

The welfare state represents the realization of the protective response from both business and citizen interests, but it is uncoordinated, ad hoc, and contradictory in its creation. Until the welfare state becomes purposeful in its manifestation, until it carries with it the mission of serving the greater social good, it will continue to deteriorate and to be usurped by monopoly capitalism and the neoliberal project. The way forward requires individuals to recognize the power of the communal and to acknowledge the impotency of the individual acting alone. Only then can individuals work to transcend the actual limits to individualism and through coordinated, collective action, redesign social institutions into structures which support authentic living and the broader flourishing of individuals. 


\section{References}

Baran, Paul A. The Political Economy of Growth. New York: Monthly Review Press, 1957.

Center for Responsive Politics. http://www.opensecrets.org (accessed).

Dale, Gareth. Karl Polanyi: the Limits of the Market. Cambridge: Polity Press, 2010.

Dumenil, Gerard, and Dominique Levy. The Crisis of Neoliberalism. Cambridge, MA: Harvard University Press, 2011.

Foster, John B. "Monopoly Capital at the Turn of the Millennium." Monthly Review 51, 11 (2000): $1-18$.

Foster, John B. The Faltering Economy: The Problem of Accumulation under Monopoly Capitalism. New York: Monthly Review Press, 1984.

Harvey, David. A Brief History of Neoliberalism. Oxford: Oxford University Press, 2005.

Heilbroner, Robert L. The Nature and Logic of Capitalism. New York: W. W. Norton and Company, 1985.

Lichtenstein, Peter M. An Introduction to Post-Keynesian and Marxian Theories of Value and Price. Armonk: M. E. Sharpe, Inc., 1983.

McClintock, Brent. "Whatever Happened to New Zealand? Neoliberalism Reconsidered.” Journal of Economic Issues 32, 2 (1998):497-503.

Mott, Tracy. "In What Sense Does Monopoly Capital Require Monopoly? An Essay on the Contribution of Kalecki and Steindl." In The Economic Surplus in Advanced Economies., edited by J. B. Davis, 114-129. New Directions in Modern Economics series. Aldershot, U.K.: Elgar, 1992. 
Piven, Frances Fox. "Neoliberal Social Policy and Labor Market Discipline." In What's Class Got To Do With It? American Society in the Twenty-first Century, edited by M. Zweig, 113-124. Ithaca: ILR Press, 2004.

Polanyi, Karl. The Great Transformation: The Political and Economic Origins of Our Time.

Boston, MA: Beacon Press, 1944.

Stanfield, J. Ron. "The Fund for Social Change." In The Economic Surplus in Advanced Economies., edited by J. B. Davis, 130-148. Aldershot, U.K.: Elgar, 1992

Stanfield, J. Ron. "A Revision of the Economic Surplus Concept." In The Faltering Economy: The Problem of Accumulation under Monopoly Capitalism, edited by J. B. Foster, 251-261. New York: Monthly Review Press, 1984.

Stanfield, J. Ron. "Limited Capitalism, Institutionalism, and Marxism." Journal of Economic Issues 11, 1 (1977): 61-71.

Stanfield, James Ronald, and Jacqueline Bloom Stanfield. "Reconstructing the Welfare State in the Aftermath of the Great Capitalist Restoration.” In Inequality: Radical Institutionalist Views on Race, Gender, Class, and Nation, edited by W. M. Dugger, 127-139. Westport, Connecticut and London: Greenwood Press, 1996.

Veblen, Thorstein. The Theory of Business Enterprise. New York: Cosimo, 2005.

Veblen, Thorstein. The Theory of the Leisure Class. Oxford: Oxford University Press, 2007.

Wrenn, Mary V. "Unveiling and Deconstructing the Enabling Myths of Neoliberalism through Immanent Critique" Journal of Economic Issues 48, 2 (2014): 477-484.

Wrenn, Mary V. "The Economic Surplus as a Fund for Social Change and Post-Neoliberal Governance." Forum for Social Economics 40, 1 (2010): 99-117. 